though small shocks and tremors have occurred very occasionally in the past. That the present shock released only a very small amount of energy, thus being no exception, is shown by the facts that no damage has been reported in this well-populated region, and that the earthquake was not registered on the seismograms obtained at Kew.

\section{American Association: Columbus Meeting}

Trie one hundred and fifth meeting of the American Association for the Adrancement of Science is being held during December 27-Jnnuary 2 at Columbus, Ohio. General sessions will be held on December 27, when Dr. Wesley C. Mitchell, of Columbia University, will deliver an address as retiring president of the Association on "The Public Relations of Science"; on December 28, when Dr. Kirtley F. Mather, of Harvard University, will deliver the annual address arranged jointly by the Association and the Society of Sigma Xi, taling as his subject "The Future of Ian as an Inhabitant of the Earth"; on December 20, when Dr. Julian S. Huxloy will deliver the first address in tho United States under the arrangement between the American and British Associations to provido lecturers in alternate years, speaking on "Science, War and Reconstruction"; and on December 29, when Dean Marjorie Nicolson of Smith College, will deliver the annual address under the auspices of the United Chapters of Phi Beta Kappa, and will spenk on "Science and Literature". Symposia have been arranged on "Isotopes", "Photosynthesis", "Speciation", "The Relation of Ecology to Human Welfare", "Defence Mechanisms in Plants and Animals", "The Internal Environment and Behaviour", "Effects of Science upon Human Beings"and "Blood, Heart and Cireulation", among other topies.

\section{Awards of the Geological Society}

Tine following awards of the Geological Society of London have recently been announced : the Wollaston Medal to Mr. Henry Woods, formerly University lecturer in palæontology in the University of Cambridge, in recognition of the value of his researches into the mineral structure of the earth, especially his studies of fossil Mollusca and Crustacea from the Cretaceous formations of Great Britain, Africa and New Zealand; the Murchison Medal to Prof. Arthur Holmes, professor of geology in the University of Durham, in recognition of the value of his petrological researches and of his stimulating studies concerning the composition and physical state of the earth's interior; the Lyell Medal to Prof. H. L. Hawkins, professor of geology in the University of Reading, for his eminence in palxontology, particularly in his studies of the Echinoidea, and for his researches in Eocene stratigraphy; the Wollaston Fund to Miss Dorothea NI. A. Bato for her investigations of Pleistocene mammalian faunas in Palestine and the Mediterranean; the Murchison Fund to Archibald Gordon Macgregor, for his petrological researches into Scottish rocks and his work on the geology of Monserrat ; a moiety of the Lyell Fund to Mliss Dorothy
Hill, for her researches on Palæozoic corals; another moiety of the Lyell Fund to Mrr. L. H. Tonks, for his work on the Carboniferous rocks of Lancashire and Northumberland.

\section{Announcements}

Prof. F.. G. DonNan, emeritus professor of chemistry in the University of London, has had conferred on him the honorary degree of D.Sc. of the National University of Ireland.

Dr. Mary Evelyn Laing MicBain, formerly of the University of Bristol and now of Stanford University, California, has been elected national president of the American Women's Chemical Honor Society, Iota Sigma Pi, for the new triennium. The Society comprises 2,500 women chemists. The new secretary is Dr. I. Nacy Hoobler, director of the Research Laboratory for the Children's Fund of Michigan.

A Uxiversity of Poland Abroad was instituted at a meeting held in the Polish Library, Paris, on December 1.

Ir is reported in The Times that many of the staff and students of the University of Poznan are being held under arrest as hostages. It is belioved that the intention is to repress Polish culture and science in this overwhelmingly Polish provinco.

ThE University of Bern has awarded the first international prize for researches on encephalitis to the Italian neurologist, Dr. Beppino Disertori.

The January meeting of the Pathological Society of Great Britain and Ireland will bo held on January 12 in the Department of Pathology at Cambridge and not at Guy's Hospital.

Tue Iondon Scientific Film Society proposes to open its 1939-10 season early in the New Year. The Society would be glad to hear from readers of NATURE of films on scientific subjects, either completed or in the process of production, which could be considered for inclusion in the Society's programmes. Applications for membership should bo sent to the Secretary, L.S.F.S., 30 Bedford Row, London, W.C.I. The subscription for the season is $10 s$. or $15 s$., the higher rate entitling the subscriber to the better seats at the shows of the Society.

Erratudr.-Referring to his communication entitled "A Peculiar Phenomenon Observed in Larval Populations of the Flour Beetle Tribolium confusum Duv.", Prof. John Stanley writes that the appenrances of the various larval instars as indicated in Fig. 1 were given incorrectly in his original communication. They should read as follows : first instar 6.04 days, second instar 8.47 , third instar $12 \cdot 10$, fourth instar $15 \cdot 13$, fifth instar $18 \cdot 40$, sixth instar $21 \cdot 74$. 